\section{The magnitude of intimate partner violence in Brazil: portraits from 15 capital cities and the Federal District}

\author{
Magnitude da violência entre parceiros íntimos \\ no Brasil: retratos de 15 capitais e Distrito Federal
}

\author{
Michael Eduardo Reichenheim 1 \\ Claudia Leite Moraes 1 \\ André Szklo 2 \\ Maria Helena Hasselmann ${ }^{3}$ \\ Edinilsa Ramos de Souza 4 \\ José de Azevedo Lozana 2 \\ Valeska Figueiredo 2
}

\footnotetext{
1 Instituto de Medicina Social, Universidade do Estado do Rio de Janeiro, Rio de Janeiro, Brasil.

2 Coordenação de Prevenção

e Vigilância, Instituto Nacional de Câncer,

Rio de Janeiro, Brasil.

3 Instituto de Nutrição,

Universidade do Estado do Rio de Janeiro,

Rio de Janeiro, Brasil.

4 Escola Nacional de Saúde Pública Sergio Arouca, Fundação Oswaldo Cruz, Rio de Janeiro, Brasil.

Correspondence M. E. Reichenheim Instituto de Medicina Social, Universidade do Estado do Rio de Janeiro. Rua São Francisco Xavier 524, 7o andar

Rio de Janeiro, $R J$ 20559-900, Brasil. michael@ims.uerj.br
}

\begin{abstract}
This paper concerns the prevalence of intimate partner violence in 15 State capital cities and the Federal District of Brazil. A population-based multi-stage survey in 2002/2003 involved 6,760 15-69-year-old women (respondents). Using the Conflict Tactics Scales - Form R, the overall prevalence of psychological aggression and "minor" and severe physical abuse within couples was $78.3 \%, 21.5 \%$, and $12.9 \%$, respectively. Prevalence rates varied distinctively between cities. For instance, total physical abuse ranged from $13.2 \%$ to $34.8 \%$. On the whole, prevalence was higher in the North and Northeast cities than in the Southeast, South, and Central West. Also, all types of intimate partner violence were more frequent in couples including women who were younger ( $<25$ years) and had less schooling $(<8$ years). After stratifying by gender, although women tended to perpetrate at least one act of physical abuse more often, scores were consistently higher among male partners who were perpetrators. The results are compared to international findings. Regional, demographic, and gender differentials are discussed in light of the growing role of the Brazilian health sector in relation to intimate partner violence.
\end{abstract}

Domestic Violence; Cross-sectional Studies; Prevalence

\section{Introduction}

Intimate partner violence is now recognized as a major phenomenon worldwide and a serious public health problem 1 . The world report on violence and health by the World Health Organization (WHO) reports lifetime prevalence of violence against women as high as $69 \%(\mathrm{Ni}$ caragua) or thresholds above $50 \%$ covering the 12 months prior to the surveys (West Bank and Gaza Strip) 1.

The wide range of negative consequences of violence for individual health has also played a relevant role in awareness-raising and incorporating intimate partner violence into the public health agenda. Studies have highlighted that women subject to intimate violence are more prone to a wide range of problems. These include both physical problems, essentially related to physical and sexual abuse, and interpersonal, familial, and social problems, resulting principally from permanent stress, disappointment with the partner, and lack of hope in changing the situation of violence 2,3,4.

Although present in various reports and documents over the centuries, "violence against women" ("spouse abuse" or "wife battering") only began to occupy a more prominent place in the debates and lead to concrete action in the latter half of the $20^{\text {th }}$ century, more precisely in the late 1960 s and early 70 s 5 . The process began in Europe and North America, but even 
in the United States, where this trend was sharpest, it took 20 years for the aware-raising to lead to legislation and effective measures. Only in the early 1990s were comprehensive laws enforced and effective resources allocated to deal with gender violence 5 .

The recognition of and the debate on intimate partner violence are somewhat more recent in Brazil. It was not until the early 1980s that the country joined the overall movement for gender equality and signed the Convention on the Elimination of All Forms of Discrimination against Women, passed three years previously by the United Nations General Assembly. The year 1985 witnessed the founding of the National Council for Women's Rights and the first Women's Defense Precinct (Delegacia de Defesa da Mulher - DDM) in the State of São Paulo. In 1986 the first Special Precinct for Women (Delegacia Especial de Atendimento à Mulher - DEAM) was implemented in the city of Rio de Janeiro.

These last 15 years have seen substantial progress in the political and social debate on issues related to violence in general and particularly that against women. In 1988 the Brazilian government fully ratified the entire 1979 Convention, and in 1995 Brazil also signed the Inter-American Convention on the Prevention, Punishment, and Eradication of Violence against Women, a meeting that came to be known as the Convention of Belém do Pará (http://64. 233.187.104/search?q=cache:q591IIuuuHcJ:w ww.saude.rj.gov.br/apav/convencao_belem.do c+convencao_belem.doc\&hl=pt-BR, accessed on 29/Nov/2005). Since then, various important laws have been enacted (National Act 10.778. https://www.planalto.gov.br/ccivil_03/Leis/20 03/L10.778.htm, accessed on 02/Jun/2005; Lei Federal n. 10.886. https:/ /www.planalto.gov.br/ ccivil_03/_Ato2004-2006/2004/Lei/L10. 886 .htm, accessed on 16/Jun/2005). More recently the Special Secretariat for Women's Policy was created. In its National Plan (https:// www.planalto.gov.br/ccivil_03/_Ato2004-2006/ 2005/Decreto/D5390.htm, accessed on 16/Jun/ 2005), the Secretariat clearly stated the importance of curbing gender violence in order to achieve full citizens' rights. Incorporation into the sphere of the Ministry of Health has also been recent, through the drafting of the $\mathrm{Na}$ tional Policy for the Reduction of Morbidity and Mortality from Accidents and Violence 6 and the National Plan for the Prevention of Violence 7.

In the midst of this political and legislative impetus, organized civil society has also focused more closely on violence. The mass media have focused increasingly on the issue, both in news stories on specific cases and incorporating the issue into more generic stories or dramatizations for television ${ }^{8}$. Pressure by public opinion, the national women's movement, and awareness-raising of numerous professionals, including those in the health field, have also led to major strides in the field of targeted interventions. Women's shelters have been organized, and help groups for perpetrators have been set up in some States. Rich experiences have emerged with various actions in different health services, as well as evaluation and research groups increasingly backed by specific support for dealing with the issue.

Nevertheless, it is still surprising that in light of the growing concern over the problem of family violence, there are still few studies on its magnitude. And the research is even scarcer if one looks for studies focusing on intimate partner violence. The few existing studies tend to be based on clienteles limited to health services and public security $9,10,11,12,13,14,15$ or, although population-based, are limited to one or two cities or even just selected neighborhoods $1,16,17,18$. Most are limited to physical or sexual abuse, leaving out psychological aggression, which is likewise harmful to the health of the parties involved as other forms of intimate violence. Although they may contribute orientation concerning the problem's magnitude in Brazil, none of the studies thus far is comprehensive or representative of a national profile. Another important aspect is that the prevailing focus is on intimate violence with the woman as victim and the male partner as perpetrator. According to the legislation cited above, the scientific literature has not focused on the conflicts and possible aggressions emerging within the couple, i.e., in the relations between intimate partners themselves.

Aimed at filling these important gaps, the current study launches the dissemination of findings on intimate partner violence in the Household Survey on Risk Behaviors and Reported Morbidity from Non-Communicable Diseases (Inquérito Domiciliar sobre Comportamentos de Risco e Morbidade Referida de Agravos não Transmissíveis - IDCRMRANT) 19, the first major population-based survey in Brazil specifically concerning this issue. As a first step towards an improved understanding of the origins, causes, and consequences of intimate partner violence in the country and principally aimed at establishing a benchmark for future studies, this article presents a portrait of the psychological and physical aggressions involving couples in 15 Brazilian State capitals and the Federal District (Brasília). 


\section{Material and methods}

\section{Design, sampling procedure,} and study population

The IDCRMRANT was a cross-sectional population-based study conducted in 2002/2003, with a target population consisting of individuals 15 years or older residing in the Federal District and 15 Brazilian State capitals: Manaus, Belém, Fortaleza, Natal, João Pessoa, Recife, Aracaju, Belo Horizonte, Vitória, Rio de Janeiro, São Paulo, Curitiba, Florianópolis, Porto Alegre, and Campo Grande. Although the choice of these cities was conditioned by logistic and operational factors, all the country's regions are represented by at least two cities.

The sampling model was based on selfweighted clusters with two-stage selection 20 . The primary sampling units were census tracts and the secondary units were households. Census tract selection probability was proportional to the number of households existing at the time of the population census. Aimed at respecting the self-weighting principle, the second stage sampling fraction was specified as a function of the ratio between the mean size and number of households per tract. From a target population of $24,426,350$, a total of 26,003 individuals were sampled, belonging to 11,204 occupied households. Specifically, the study's target population concerns women from 15 to 69 years of age with some type of stable heterosexual relationship, including married women and those living with a partner at the time of the interview, as well as those with some intimate relationship lasting a month or more in the 12 previous months. With the sample, this figure is estimated to correspond to $70.5 \%$ of the women 15 to 69 years of age in the population. The number of women actually tapped in the analysis is shown city-by-city in the first table in the Results section. The overall mean percentage of missing data was $6.3 \%$, varying from $3.8 \%$ in Fortaleza to $9.9 \%$ in Rio de Janeiro. Still, using as a premise the known proportion of stable relationships in women who were actually interviewed, it is possible to project an overall $4.4 \%$ of missing data among the eligible women, with the extremes also belonging to the two cities cited above (2.8\% to $6.9 \%$, respectively).

\section{Variables and measuring instruments}

The multidimensional questionnaire created for the study was based on various known and commonly used measuring instruments, cov- ering demographic and socioeconomic information; risk behaviors; referred morbidity; quality of life and functional status; access to exams; traffic accidents; and intimate partner violence.

Of central interest to the current article, the module covering intimate partner violence was based entirely on the Conflict Tactics Scales (CTS) - Form $\mathrm{R} 21$. This instrument was adapted for use in Brazil, and the Portuguese version can be found in the attachment to Hasselmann \& Reichenheim 22 . The CTS proposes to measure strategies by family members to resolve possible clashes and indirectly to capture situations of conflict or violence. The instrument uses 18 items in the scoring process, comprising three scales 21 . That of "reasoning" consists of using persuasion through moderate and sensible language (3 items); verbal aggression relates to the use of insults and threats with the intention of symbolically hurting and injuring the other party (6 items); and physical aggression assesses the explicit use of physical force to resolve conflicts (9 items). The latter encompasses two sub-scales, one on what are considered "minor" events (3 items) and another that covers severe acts (6 items).

Each item refers to both members of the couple as perpetrators. In the current study, for operational purposes, the information on the respective intimate partner was obtained by proxy from the responding woman. It is worth pointing out that to focus primarily on intimate partner violence within the sphere of the couple tends to mitigate a possible information bias. This combination increases the probability of a mutual canceling 22 , since on the one hand there is a known propensity to overestimate the violence perpetrated by the partner when measured by proxy, and on the other there is a tendency to underreport one's own acts 21,23 . In the current study, a "positive" event is defined as the report of at least one item in the respective scale. From the perspective of violence concerning the couple, the positive event is characterized by at least one of the members reporting an item. Each scale's score is formed by the sum of the respective items. The recall period recommended and actually used in the study covers the 12 months prior to the interview.

\section{Data collection}

The data were collected in two different periods. The cities of Manaus, Belém, Fortaleza, João Pessoa, Belo Horizonte, Rio de Janeiro, Curitiba, Porto Alegre, and the Distrito Federal 
were visited in 2002. Data were collected in $\mathrm{Na}$ tal, Recife, Aracaju, Vitória, São Paulo, Florianópolis, and Campo Grande in 2003. To conduct the interviews, preferably the head of household (whether male or female) was contacted and provided the information on the list of household members. All the eligible interviewees (15 years or older) were contacted subsequently to conduct the individual interviews, preferably in a reserved place. The module on intimate partner violence was applied specifically to eligible women amidst other modules dealing exclusively with information on women's matters, a strategy that allowed greater privacy. Avoiding the partner's presence attempted to minimize the propensity to conceal or deny any violence the women had suffered, not only because of some instinct to protect the partner, but also for fear of subsequent retaliation leading to escalated violence 24 . It was also helpful that only previously trained female interviewers were deployed to apply the modules specifically targeting women.

Anonymous and voluntary participation was ensured to the research subjects. Informed consent, signed by the interviewees themselves or by the parent or guardian (for individuals under 18 years), was required for participation. The study complied with the criteria set by the Brazilian National Council on Research Ethics (CONEP) 25

\section{Data entry, processing, and analysis}

To facilitate verification of incoherencies and/or inconsistencies, the data were keyed in centrally, in parallel with the data collection. The data entry application was developed by the IT Division of the National Cancer Institute (INCA) using Delphi language and the Oracle database platform. Processing of variables and data analysis used Stata 9 (Stata Corporation, College Station, Estados Unidos). The analysis used the application's SVY suite to deal adequately with the clustering sample structure and allow incorporation of expansion fractions in the analyses 26,27 .

Further details on the sampling procedures, data collection instruments, fieldwork and its quality control, and statistical basis for data analysis can be found in IDCRMRANT 19

\section{Results}

Table 1 shows the prevalence of verbal aggression and the shades of physical abuse involving couples in the 16 cities. In the aggregate, slightly more than three-fourths of the women reported some psychological aggression between the members of the couple during the 12 months prior to the interview. Still, this figure tended to vary by city, from $61.7 \%$ in Campo Grande to $85.6 \%$ in Belo Horizonte.

Prevalence of minor physical abuse varied from $12.8 \%$ in João Pessoa to $34.7 \%$ in Belém. Serious physical abuse was some $40 \%$ less, but with a distribution similar to that of minor abuse. Florianópolis (8.2\%) and Belém $(22.1 \%)$ were the two extremes. For the cities as a whole, the prevalence of minor and serious physical abuse was $21.5 \%$ and $12.9 \%$, respectively.

For a better perception of the phenomenon's regional distribution, Figure 1 highlights the profile of total physical violence involving at least one member of couple for each of the cities. Notice the two dashed lines around the $20 \%$ and $25 \%$ prevalence cutoffs. Even considering the confidence intervals (whiskers in Figure 1), there is a perceptible gradient. Except for João Pessoa, it is possible to distinguish the North and Northeast as having higher prevalence rates than the other regions and also to identify two other cities with levels clearly below the others (Campo Grande and Florianópolis). All the State capitals in the Southeast have intermediate prevalence rates.

Despite the eccentricity of João Pessoa, a formal analysis comparing the cities of the North and Northeast with those of the South, Southeast, and Central West (including the Federal District) shows a statistically significant difference $(p=0.000)$. In the latter group, the prevalence of total physical violence for the cities as a whole is $20.8 \%$ (95\%CI: $18.9 ; 22.9$ ), while reaching $29.8 \%$ (95\%CI: $27.4 ; 32.3$ ) in the North and Northeast. This difference of approximately $45 \%$ is true for minor physical violence, but is even more striking for serious acts. From $11.2 \%(95 \%$ CI: $9.7 ; 12.8)$ in the South, Southeast, and Central West, the prevalence of severe violence increases to $19 \%$ (95\%CI: 17.1 ; 21.1 ) in the North and Northeast, a $70 \%$ rise. Notice that this contrast is not repeated in psychological aggression $(p=0.811)$ for which the prevalence rates are quite close in the two different groups of regions: $78.2 \%$ (95\%CI: 76.0 ; $80.3)$ and $78.6 \%$ (95\%CI: $76.5 ; 80.6)$, respectively.

Table 2 shows each city's profile of total physical abuse in couples, comparing the rates for female adolescents or young adult women $(<25$ years) with those for women 25 or older. Although not necessarily significant at the 5\% level when focusing on each city separately, the prevalence rates in couples with younger women are consistently higher. This overall ob- 
Profile of intimate partner violence: verbal aggression (psychological) and minor and severe physical abuse in couples, in 15 State capitals and the Federal District, Brazil, 2002/2003.

\begin{tabular}{|c|c|c|c|c|}
\hline \multirow[t]{2}{*}{ Location } & \multirow[t]{2}{*}{$\mathbf{N}^{\star}\left(\mathbf{N}_{\exp }\right)$} & \multirow[t]{2}{*}{ Verbal aggression } & \multicolumn{2}{|c|}{ Physical abuse } \\
\hline & & & Minor $(\%)^{\star \star}$ & Severe (\%) \\
\hline \multirow[t]{2}{*}{ Manaus } & 465 & 82.8 & 33.3 & 20.2 \\
\hline & $(345,112)$ & {$[77.6 ; 87.9]$} & {$[27.8 ; 38.9]$} & {$[15.5 ; 24.9]$} \\
\hline \multirow[t]{2}{*}{ Belém } & 363 & 84.9 & 34.7 & 22.1 \\
\hline & $(272,688)$ & {$[80.7 ; 89.1]$} & {$[28.3 ; 41.2]$} & {$[17.5 ; 26.6]$} \\
\hline \multirow[t]{2}{*}{ Fortaleza } & 579 & 79.1 & 29.0 & 20.7 \\
\hline & $(586,684)$ & {$[75.5 ; 82.6]$} & {$[24.1 ; 34.0]$} & {$[16.1 ; 25.3]$} \\
\hline \multirow[t]{2}{*}{ Natal } & 330 & 76.6 & 24.8 & 15.7 \\
\hline & $(172,920)$ & {$[70.8 ; 82.5]$} & {$[18.7 ; 30.9]$} & {$[10.9 ; 20.5]$} \\
\hline \multirow[t]{2}{*}{ João Pessoa } & 286 & 64.1 & 12.8 & 8.6 \\
\hline & $(129,260)$ & {$[56.4 ; 71.8]$} & {$[8.2 ; 17.4]$} & {$[4.5 ; 12.8]$} \\
\hline \multirow[t]{2}{*}{ Recife } & 389 & 73.5 & 24.4 & 18.8 \\
\hline & $(369,939)$ & {$[68.1 ; 80.0]$} & {$[18.8 ; 30.1]$} & {$[14.4 ; 23.1]$} \\
\hline \multirow[t]{2}{*}{ Aracaju } & 336 & 82.1 & 22.6 & 14.0 \\
\hline & $(119,616)$ & {$[76.6 ; 87.7]$} & {$[17.8 ; 27.4]$} & {$[9.7 ; 17.6]$} \\
\hline \multirow[t]{2}{*}{ Belo Horizonte } & 549 & 85.4 & 21.6 & 11.7 \\
\hline & $(570,069)$ & {$[82.3 ; 88.6]$} & {$[17.9 ; 25.4]$} & {$[9.0 ; 14.4]$} \\
\hline \multirow[t]{2}{*}{ Vitória } & 307 & 73.9 & 18.9 & 13.4 \\
\hline & $(70,303)$ & {$[69.0 ; 78.8]$} & {$[12.7 ; 25.1]$} & {$[7.8 ; 18.9]$} \\
\hline \multirow[t]{2}{*}{ Rio de Janeiro } & 657 & 79.3 & 21.0 & 12.5 \\
\hline & $(1,369,845)$ & {$[75.9 ; 82.8]$} & {$[17.0 ; 24.9]$} & {$[9.5 ; 15.4]$} \\
\hline \multirow[t]{2}{*}{ São Paulo } & 495 & 77.2 & 18.4 & 9.9 \\
\hline & $(2,929,905)$ & {$[73.0 ; 81.3]$} & {$[14.6 ; 22.2]$} & {$[7.0 ; 12.8]$} \\
\hline \multirow[t]{2}{*}{ Curitiba } & 574 & 78.7 & 17.5 & 10.0 \\
\hline & $(383,984)$ & {$[75.0 ; 82.7]$} & {$[14.3 ; 20.7]$} & {$[7.4 ; 12.6]$} \\
\hline \multirow[t]{2}{*}{ Florianópolis } & 326 & 82.8 & 15.3 & 8.2 \\
\hline & $(85,086)$ & {$[79.5 ; 86.1]$} & {$[10.6 ; 19.9]$} & {$[4.6 ; 11.8]$} \\
\hline \multirow[t]{2}{*}{ Porto Alegre } & 346 & 77.4 & 21.6 & 11.8 \\
\hline & $(303,597)$ & {$[72.3 ; 82.5]$} & {$[17.5 ; 25.8]$} & {$[7.8 ; 15.7]$} \\
\hline \multirow[t]{2}{*}{ Campo Grande } & 251 & 61.7 & 15.9 & 9.5 \\
\hline & $(151,604)$ & {$[52.4 ; 71.0]$} & {$[11.3 ; 20.4]$} & {$[5.9 ; 13.1]$} \\
\hline \multirow[t]{2}{*}{ Federal District } & 521 & 77.1 & 21.6 & 13.9 \\
\hline & $(510,048)$ & {$[73.3 ; 81.0]$} & {$[17.1 ; 26.0]$} & {$[10.4 ; 17.4]$} \\
\hline \multirow[t]{2}{*}{ Total (aggregate) } & 6774 & 78.3 & 21.5 & 12.9 \\
\hline & $(8,370,660)$ & {$[76.6 ; 80.0]$} & {$[19.9 ; 23.2]$} & {$[11.6 ; 14.2]$} \\
\hline
\end{tabular}

* Values refer to women respondents 15 to 69 years of age with partners. Totals (by city and aggregate) actually used to calculate proportions varied slightly according to the amount of missing data for each variable, i.e., $1 \%$ for verbal aggression and $0.2 \%$ and $0.18 \%$ for the two forms of physical abuse, respectively. In parentheses is the female population from 15 to 69 years of age with partners (estimated after expansion, subtracting the equivalent fraction of missing data).

** $95 \%$ confidence interval in square brackets. Analysis takes into account the census tract as Primary Sampling Unit and the expansion factor.

servation is corroborated by a formal aggregate analysis (the set of 16 cities), which shows a clearly significant difference $(p=0.000)$ between the prevalence of $28.2 \%$ (95\%CI: 25.68 ; 31.0 ) in younger women and $21.2 \%$ (95\%CI: $19.3 ; 23.1)$ in those over 25.

Table 2 also shows a comparison by schooling of the woman (interviewee). Prevalence rates for total physical violence in couples where the woman has an incomplete primary education are consistently higher than in the other group. With rare exceptions, the magnitudes reach thresholds that are consistent with the aggregate for the North and Northeast. Placed in perspective, the prevalence of intimate partner violence increases from 18.9\% (95\%CI: 17.3 ; 


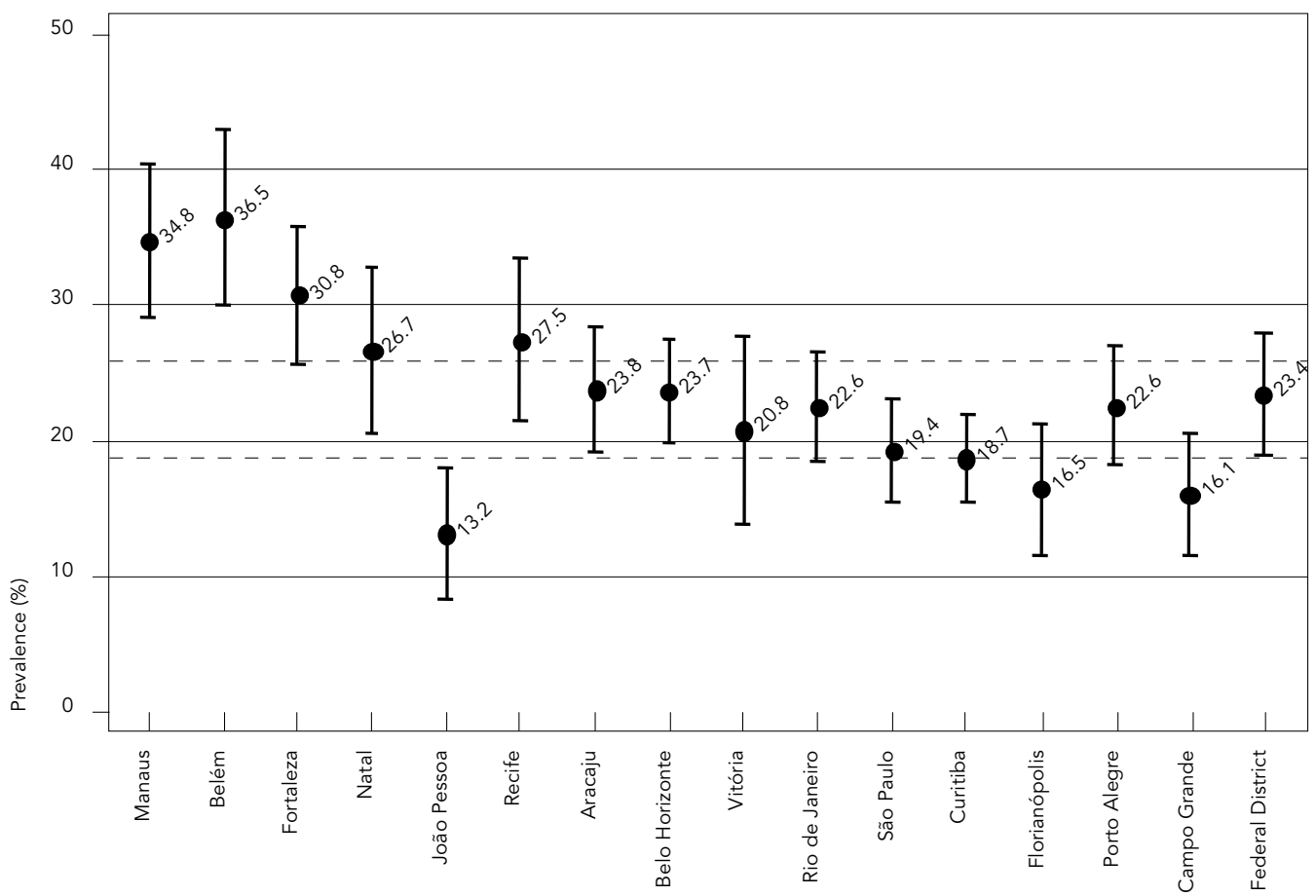

20.7) in couples where the woman has a complete primary education to $31 \%$ (95\%CI: 28.0 ; $34.2)$ for those with less schooling. As in relation to age, this difference is statistically significant $(\mathrm{p}=0.000)$.

Figure 2 shows the city-by-city profile of any physical abuse in the previous 12 months, focusing now on the perpetrator. There is regular evidence that the woman tends to perpetrate at least one violent act more frequently than the respective male partner. In the 16 cities as a whole, the prevalence rates for total physical abuse by female and male perpetrators in the couple are $19.7 \%$ (95\%CI: $18.2 ; 21.2)$ and $14.6 \%$ (95\%CI: 13.3; 15.9), respectively. The contrast is similar when focusing on minor physical abuse, but is about one-half for serious physical abuse: 10.4\% (95\%CI: 9.3; 11.5) and 7.2\% (95\%CI: 6.3; 8.1). Discerning between the uni- and bi-directional situations, although in half of the situations the acts are reciprocal, there is also a preponderance of women perpetrators when the (total) physical abuse is one-way. Expressed in numbers, the perpetration exclusively concerns women and men in 8.3\% (95\%CI: 7.4; 9.3) and
$3.2 \%$ (95\%CI: 2.6 ; 3.8) of the couples, respectively, and in $11.2 \%(95 \%$ CI: $10.1 ; 12.3)$ the abuses are committed by both partners.

Although women commit physical abuse more frequently than their male partners, the picture changes when focusing (according to severity) on the mean number of acts perpetrated among those who are actually perpetrators. As shown in Table 3, except for Vitória, the mean score of the acts always tends to be higher in men when dealing with serious events. The overall mean for the 16 cities is 1.70 (95\%CI: $1.63 ; 1.78$ ) acts per woman, but increases to 2.31 (95\%CI: 2.12 ; 2.50 ) per male perpetrator. A formal statistical analysis reinforces this contrast. Regression of the physical abuse score by gender and city produces a p-value of 0.000 by gender in the case of serious physical abuse, but only 0.357 for minor physical abuse.

\section{Discussion}

Given the disparity between the methods used in nationwide surveys and the population types 
Profile of intimate partner violence: prevalence (in \%)* of total physical abuse (minor + severe) in the couple, stratified by woman's age and schooling (primary), in 15 State capitals and the Federal District, Brazil, 2002/2003.

\begin{tabular}{|c|c|c|c|c|c|c|}
\hline Location & $<25$ years & $\begin{array}{c}\text { Age } \\
\geq 25 \text { years }\end{array}$ & $p$-value & $\begin{array}{c}\text { Incomplete } \\
\text { ( } \leq 7 \text { years) }\end{array}$ & $\begin{array}{l}\text { asic schooling } \\
\text { Complete } \\
\text { (> } 7 \text { years) }\end{array}$ & $\mathrm{p}$-value \\
\hline Manaus & $\begin{array}{c}46.0 \\
{[39.3 ; 52.7]}\end{array}$ & $\begin{array}{c}30.0 \\
{[23.1 ; 36.9]}\end{array}$ & 0.0006 & $\begin{array}{c}39.7 \\
{[30.9 ; 48.4]}\end{array}$ & $\begin{array}{c}31.2 \\
{[24.9 ; 37.4]}\end{array}$ & 0.0802 \\
\hline Belém & $\begin{array}{c}39.5 \\
{[31.2 ; 47.8]}\end{array}$ & $\begin{array}{c}35.0 \\
{[27.1 ; 42.9]}\end{array}$ & 0.3895 & $\begin{array}{c}42.0 \\
{[32.0 ; 52.0]}\end{array}$ & $\begin{array}{c}33.2 \\
{[26.2 ; 40.1]}\end{array}$ & 0.0963 \\
\hline Fortaleza & $\begin{array}{c}36.0 \\
{[29.7 ; 42.2]}\end{array}$ & $\begin{array}{c}28.8 \\
{[23.1 ; 34.5]}\end{array}$ & 0.0273 & $\begin{array}{c}40.5 \\
{[33.8 ; 47.2]}\end{array}$ & $\begin{array}{c}24.1 \\
{[18.5 ; 29.6]}\end{array}$ & 0.0000 \\
\hline Natal & $\begin{array}{c}36.8 \\
{[26.1 ; 47.4]}\end{array}$ & $\begin{array}{c}22.6 \\
{[15.8 ; 29.5]}\end{array}$ & 0.0119 & $\begin{array}{c}28.1 \\
{[19.6 ; 36.7]}\end{array}$ & $\begin{array}{c}26.6 \\
{[19.3 ; 33.8]}\end{array}$ & 0.7433 \\
\hline João Pessoa & $\begin{array}{c}16.8 \\
{[9.1 ; 24.4]}\end{array}$ & $\begin{array}{c}12.0 \\
{[6.7 ; 17.2]}\end{array}$ & 0.1919 & $\begin{array}{c}18.9 \\
{[11.4 ; 26.4]}\end{array}$ & $\begin{array}{c}8.7 \\
{[3.3 ; 14.1]}\end{array}$ & 0.0115 \\
\hline Recife & $\begin{array}{c}32.4 \\
{[22.5 ; 42.3]}\end{array}$ & $\begin{array}{c}25.7 \\
{[19.9 ; 31.5]}\end{array}$ & 0.1216 & $\begin{array}{c}44.0 \\
{[36.8 ; 51.3]}\end{array}$ & $\begin{array}{c}16.1 \\
{[10.4 ; 21.8]}\end{array}$ & 0.0000 \\
\hline Aracaju & $\begin{array}{c}27.1 \\
{[17.5 ; 36.7]}\end{array}$ & $\begin{array}{c}22.6 \\
{[19.9 ; 27.2]}\end{array}$ & 0.3619 & $\begin{array}{c}32.4 \\
{[24.7 ; 40.1]}\end{array}$ & $\begin{array}{c}18.0 \\
{[13.7 ; 22.4]}\end{array}$ & 0.0010 \\
\hline Belo Horizonte & $\begin{array}{c}32.4 \\
{[25.1 ; 39.8]}\end{array}$ & $\begin{array}{c}20.7 \\
{[16.6 ; 24.9]}\end{array}$ & 0.0024 & $\begin{array}{c}33.3 \\
{[26.1 ; 40.5]}\end{array}$ & $\begin{array}{c}18.4 \\
{[14.3 ; 22.5]}\end{array}$ & 0.0002 \\
\hline Vitória & $\begin{array}{c}27.2 \\
{[16.4 ; 38.0]}\end{array}$ & $\begin{array}{c}19.0 \\
{[11.8 ; 26.3]}\end{array}$ & 0.1401 & $\begin{array}{c}41.8 \\
{[31.1 ; 52.6]}\end{array}$ & $\begin{array}{c}13.9 \\
{[8.8 ; 19.0]}\end{array}$ & 0.0000 \\
\hline Rio de Janeiro & $\begin{array}{c}25.5 \\
{[19.2 ; 31.8]}\end{array}$ & $\begin{array}{c}21.7 \\
{[17.3 ; 26.2]}\end{array}$ & 0.2933 & $\begin{array}{c}31.7 \\
{[24.2 ; 39.2]}\end{array}$ & $\begin{array}{c}19.1 \\
{[15.0 ; 23.2]}\end{array}$ & 0.0004 \\
\hline São Paulo & $\begin{array}{c}22.0 \\
{[15.1 ; 28.9]}\end{array}$ & $\begin{array}{c}18.6 \\
{[14.3 ; 22.9]}\end{array}$ & 0.3785 & $\begin{array}{c}27.0 \\
{[19.6 ; 34.5]}\end{array}$ & $\begin{array}{c}15.6 \\
{[11.7 ; 19.5]}\end{array}$ & 0.0041 \\
\hline Curitiba & $\begin{array}{c}26.9 \\
{[20.4 ; 33.3]}\end{array}$ & $\begin{array}{c}16.2 \\
{[12.3 ; 20.2]}\end{array}$ & 0.0057 & $\begin{array}{c}24.6 \\
{[18.0 ; 31.2]}\end{array}$ & $\begin{array}{c}16.9 \\
{[12.8 ; 21.0]}\end{array}$ & 0.0572 \\
\hline Florianópolis & $\begin{array}{c}23.6 \\
{[15.3 ; 31.8]}\end{array}$ & $\begin{array}{c}14.4 \\
{[9.8 ; 19.0]}\end{array}$ & 0.0079 & $\begin{array}{c}23.2 \\
{[12.8 ; 33.6]}\end{array}$ & $\begin{array}{c}14.0 \\
{[9.1 ; 18.9]}\end{array}$ & 0.0724 \\
\hline Porto Alegre & $\begin{array}{c}29.3 \\
{[22.5 ; 36.1]}\end{array}$ & $\begin{array}{c}20.1 \\
{[14.8 ; 25.5]}\end{array}$ & 0.0346 & $\begin{array}{c}31.2 \\
{[20.2 ; 42.2]}\end{array}$ & $\begin{array}{c}19.8 \\
{[15.3 ; 24.4]}\end{array}$ & 0.0474 \\
\hline Campo Grande & $\begin{array}{c}26.5 \\
{[17.0 ; 36.1]}\end{array}$ & $\begin{array}{c}12.6 \\
{[7.8 ; 17.4]}\end{array}$ & 0.0038 & $\begin{array}{c}19.2 \\
{[10.1 ; 28.4]}\end{array}$ & $\begin{array}{c}13.2 \\
{[7.9 ; 18.4]}\end{array}$ & 0.2549 \\
\hline Federal District & $\begin{array}{c}29.1 \\
{[24.4 ; 33.6]}\end{array}$ & $\begin{array}{c}20.8 \\
{[15.4 ; 26.2]}\end{array}$ & 0.0063 & $\begin{array}{c}24.7 \\
{[17.3 ; 32.1]}\end{array}$ & $\begin{array}{c}23.2 \\
{[18.3 ; 28.2]}\end{array}$ & 0.7049 \\
\hline
\end{tabular}

* Percentage of positives. 95\% confidence interval in square brackets. Analysis takes into account the census tract as Primary Sampling Unit and the expansion factor.

they encompass, any comparison of this study's results with those of surveys conducted in other countries should be done with caution. Even so, it is worthwhile to revisit the extensive literature published by Heise et al. 28,29. Adding to two more recent references 30,31 and focusing primarily on the estimates from studies conducted in the last 15 years on the physical abuse occurring in the 12 months prior to the surveys, the prevalence rates for the 16 cities studied as a whole in the IDCRMRANT are at an intermediate level. On the one hand, the prevalence of total physical violence perpetrat- ed by men against women (14.6\%) is far higher than the mean of the estimates reported in North America (2\%); moderately higher than those from Europe (8\%) and Sub-Saharan Africa (9\%); and, excluding the extremely high level of violence observed in Korea (38\%), close to the levels found in Asia and Oceania (12\%). On the other hand, in the aggregate, the Brazilian rate is well below the mean quoted for North Africa and the Middle East (33\%). Less strikingly, the joint Brazilian rate is also lower than the Latin American average of $21 \%$, although similar to the rates reported for Mexico 


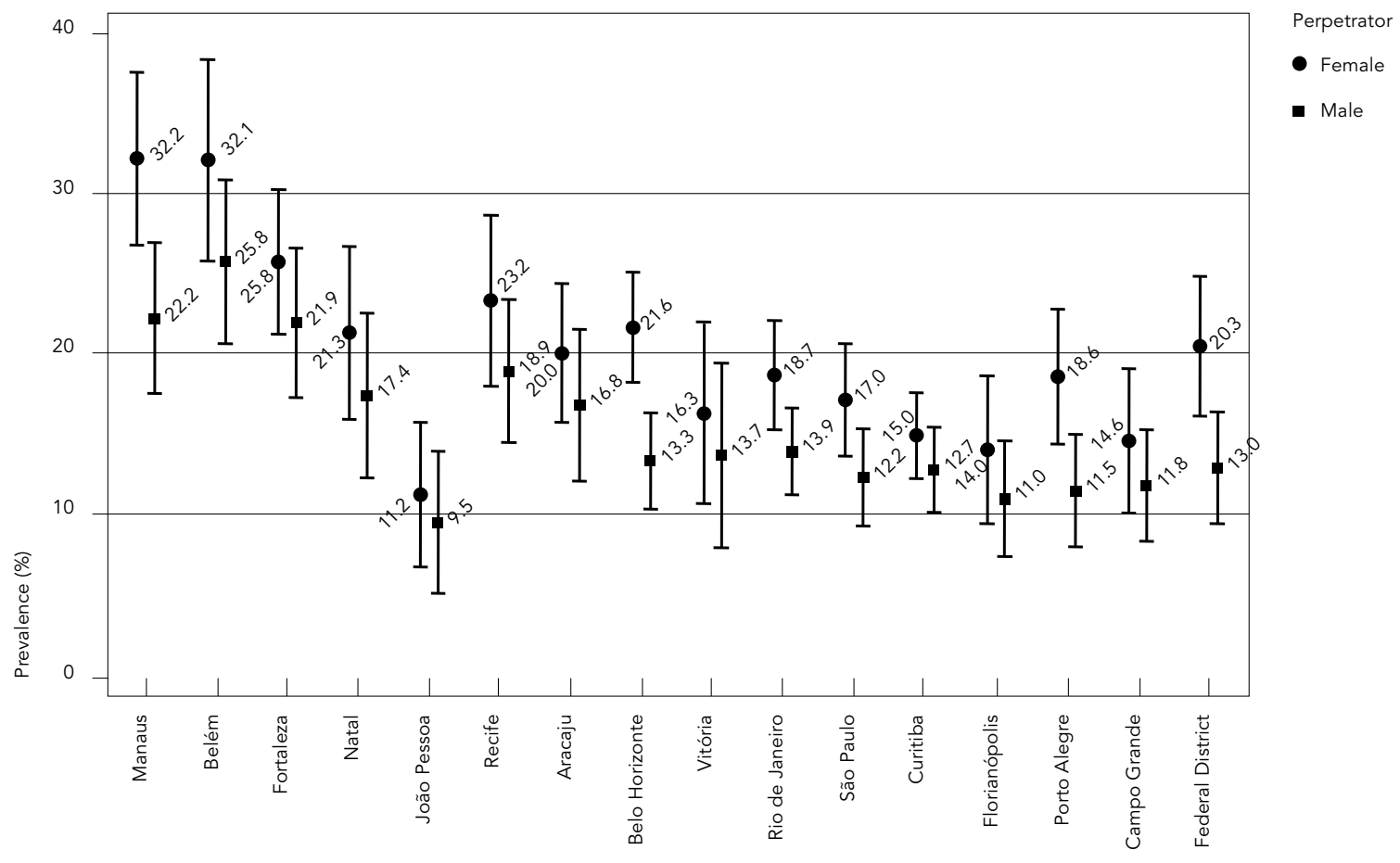

(15\%) and Uruguay (10\%). An analogous comparative profile applies to the $6.9 \%$ estimate found in IDCRMRANT with regard to serious physical violence perpetrated by men against women.

Focusing now on the perspective of the couple as a whole, one is impressed by the high frequency of intimate violence in the relationship. No less than three-fourths of the women reported at least one act of psychological aggression in the 12 months prior to the survey. Even more striking is that approximately one in five women reported an episode of physical force during the same period, with one in every seven couples involving severe acts, such as punching, beating, choking, or even brandishing or actually using a knife or firearm.

It is also possible to recognize regional subtleties. Even though the demarcation of ranges proposed here is admittedly somewhat arbitrary, it is possible to perceive (Figure 1) that as a whole the levels are intermediate in the South and Southeast, yet much higher in the North and Northeast. For example, in Manaus and
Belém (North), nearly one in four couples reported having experienced some act of physical violence during the reference period, a scenario which (as discussed above) is more similar to that of North Africa and the Middle East. At the other extreme, the comparatively low levels found in three cities (Florianópolis, Campo Grande, and João Pessoa) are surprising. The latter, capital of the Northeast State of Paraíba, is particularly noteworthy, since it is located in the region of the country with the highest rates, yet has the lowest prevalence of all 16 cities studied.

The disparities identified in the profile above clearly require follow-up and more indepth study. Several important facets from the ecological model emphasized in the WHO report merit further detail 1 . At the individual level, it would be interesting to explore the previous history of aggression in the families and the use of psychoactive substances like alcohol and illicit drugs. At the community level, it would be relevant to know the possible differences in the contexts in which social relations take place, for example focusing on the resi- 
Mean score* for minor and severe physical abuse according to perpetrator in 15 State capitals and the Federal District, 2002/2003.

\begin{tabular}{|c|c|c|c|c|c|c|}
\hline \multirow[t]{2}{*}{ Location } & \multicolumn{3}{|c|}{ Minor physical abuse } & \multicolumn{3}{|c|}{ Severe physical abuse } \\
\hline & Male & Female & $p$-value & Male & Female & $p$-value \\
\hline \multirow[t]{2}{*}{ Manaus } & 1.60 & 1.63 & 0.7215 & 1.97 & 1.85 & 0.5769 \\
\hline & {$[1.43 ; 1.76]$} & {$[1.50 ; 1.75]$} & & {$[1.57 ; 2.37]$} & {$[1.59 ; 2.11]$} & \\
\hline \multirow[t]{2}{*}{ Belém } & 1.59 & 1.67 & 0.4651 & 1.91 & 1.81 & 0.5949 \\
\hline & {$[1.42 ; 1.76]$} & {$[1.53 ; 1.81]$} & & {$[1.64 ; 2.17]$} & {$[1.58 ; 2.05]$} & \\
\hline \multirow[t]{2}{*}{ Fortaleza } & 1.79 & 1.66 & 0.1680 & 2.25 & 1.80 & 0.0274 \\
\hline & {$[1.63 ; 1.95]$} & {$[1.53 ; 1.79]$} & & {$[1.91 ; 2.59]$} & {$[1.61 ; 1.98]$} & \\
\hline \multirow[t]{2}{*}{ Natal } & 1.64 & 1.64 & 0.9945 & 2.40 & 1.54 & 0.0081 \\
\hline & {$[1.41 ; 1.86]$} & {$[1.45 ; 1.82]$} & & {$[1.82 ; 2.97]$} & {$[1.25 ; 1.83]$} & \\
\hline \multirow[t]{2}{*}{ João Pessoa } & 2.02 & 1.72 & 0.2224 & 2.31 & 1.86 & 0.3510 \\
\hline & {$[1.73 ; 2.31]$} & {$[1.46 ; 1.97]$} & & {$[1.66 ; 2.95]$} & {$[1.41 ; 2.32]$} & \\
\hline \multirow[t]{2}{*}{ Recife } & 1.75 & 2.00 & 0.0451 & 2.12 & 1.90 & 0.4090 \\
\hline & {$[1.55 ; 1.95]$} & {$[1.80 ; 2.19]$} & & {$[1.74 ; 2.51]$} & {$[1.60 ; 2.20]$} & \\
\hline \multirow[t]{2}{*}{ Aracaju } & 1.73 & 1.63 & 0.4071 & 2.22 & 1.71 & 0.1051 \\
\hline & {$[1.55 ; 1.90]$} & {$[1.41 ; 1.85]$} & & {$[1.76 ; 2.67]$} & {$[1.37 ; 2.05]$} & \\
\hline \multirow[t]{2}{*}{ Belo Horizonte } & 1.76 & 1.64 & 0.2168 & 2.35 & 1.63 & 0.0165 \\
\hline & {$[1.61 ; 1.90]$} & {$[1.51 ; 1.77]$} & & {$[1.83 ; 2.86]$} & {$[1.40 ; 1.86]$} & \\
\hline \multirow[t]{2}{*}{ Vitória } & 1.51 & 1.71 & 0.1322 & 1.50 & 1.61 & 0.7020 \\
\hline & {$[1.30 ; 1.72]$} & {$[1.55 ; 1.86]$} & & {$[1.09 ; 1.90]$} & {$[1.30 ; 1.91]$} & \\
\hline \multirow[t]{2}{*}{ Rio de Janeiro } & 1.70 & 1.73 & 0.7159 & 2.19 & 1.81 & 0.0907 \\
\hline & {$[1.53 ; 1.86]$} & {$[1.59 ; 1.87]$} & & {$[1.79 ; 2.58]$} & {$[1.53 ; 2.09]$} & \\
\hline \multirow[t]{2}{*}{ São Paulo } & 1.73 & 1.57 & 0.1793 & 2.71 & 1.51 & 0.0007 \\
\hline & {$[1.53 ; 1.93]$} & {$[1.43 ; 1.71]$} & & {$[2.15 ; 3.26]$} & {$[1.23 ; 1.79]$} & \\
\hline \multirow[t]{2}{*}{ Curitiba } & 1.61 & 1.68 & 0.6388 & 2.28 & 1.49 & 0.0134 \\
\hline & {$[1.40 ; 1.82]$} & {$[1.51 ; 1.84]$} & & {$[1.76 ; 2.79]$} & {$[1.14 ; 1.83]$} & \\
\hline \multirow[t]{2}{*}{ Florianópolis } & 1.51 & 1.47 & 0.8104 & 1.76 & 1.55 & 0.4641 \\
\hline & {$[1.25 ; 1.77]$} & {$[1.25 ; 1.70]$} & & {$[1.26 ; 2.26]$} & {$[1.12 ; 1.97]$} & \\
\hline \multirow[t]{2}{*}{ Porto Alegre } & 1.68 & 1.64 & 0.8125 & 1.90 & 1.68 & 0.5342 \\
\hline & {$[1.42 ; 1.95]$} & {$[1.43 ; 1.85]$} & & {$[1.26 ; 2.53]$} & {$[1.27 ; 2.09]$} & \\
\hline \multirow[t]{2}{*}{ Campo Grande } & 1.73 & 1.50 & 0.1521 & 2.07 & 1.54 & 0.2308 \\
\hline & {$[1.44 ; 2.01]$} & {$[1.28 ; 1.71]$} & & {$[1.28 ; 2.85]$} & {$[1.13 ; 1.95]$} & \\
\hline \multirow[t]{2}{*}{ Federal District } & 1.59 & 1.76 & 0.2169 & 2.14 & 1.76 & 0.1545 \\
\hline & {$[1.40 ; 1.78]$} & {$[1.58 ; 1.94]$} & & {$[1.67 ; 2.61]$} & {$[1.52 ; 1.99]$} & \\
\hline
\end{tabular}

* Percentage of positives. 95\% confidence interval in square brackets. Analysis takes into account the census tract as Primary Sampling Unit and the expansion factor.

dential mobility patterns, the geographic homogeneity or heterogeneity in the origins of community members, and rates of unemployment and violence in the community. At the macro-structural level, factors promoting or inhibiting violence would be relevant, such as those linked to the cultural norms governing gender relations, as well as iniquities in welfare structures related to public policies in health, education, and work 1 .

As for the frequencies of intimate partner violence in certain population subgroups, the findings are consistent with higher levels of in- timate partner violence in low-income couples and those including younger women, a profile similar to that found in other studies 1,18,32,33. In the 16 cities as a whole, the prevalence rates reach $28.2 \%$ and $31 \%$ in these strata, magnitudes that again are in keeping with the rates in North Africa and the Middle East. Even in the cities in the South, Southeast, and Central West of Brazil, the prevalence rates in these subgroups reach levels as high as in the more extreme regions as a whole.

Stratifying the data by gender can be evaluated jointly through Figure 2 and Table 3. The 
two clearly show that, as a whole, more women commit at least one act of physical violence than their respective partners, but the male partners who are perpetrators consistently commit more such acts. Among the males who had perpetrated some serious act in the previous 12 months, the mean number of acts was some one-third greater than for the respective women. This evidence is fully consistent with the literature using a similar approach. Various studies have shown women as more frequent perpetrators, while women are at a clear disadvantage in situations in which they are the victims 34,35,36. For example, a study in Brazil shows a threefold risk of a victimized woman suffering blatantly harmful consequences, such as requiring emergency care for injuries inflicted by the male perpetrator 18 .

The current finding that women perpetrate as many or more violent acts than their partners corroborates the impression of many researchers in the field, that population-based surveys are preferentially prone to capture moderate forms of violence, which are rather common in daily relations between members of the couple, where women participate actively in the processes, often reacting to constant subliminal psychological aggression by the male partner 37,38,39. Meanwhile, the evidence of more accumulated acts perpetrated by the male partner, in keeping with findings from other studies that the consequences are worse for women, appears to show that surveys are somehow capable of capturing a second pattern of intimate partner violence postulated by the experts. According to this second pattern, there is an escalation of violence characterized by multiple forms of threats and abuse by men against women, often culminating in heinous scenarios requiring immediate reporting and drastic legal action 39,40.

At any rate, one cannot hastily conclude that violence involving intimate partners is quantitatively and qualitatively symmetrical in relation to gender. Power structures and domination must be contemplated and discussed, since the potential for hurting and severely injuring the other is not reciprocal. The second point is that there are different scenarios for clashes. Some are alarming, calling the attention of the media and the general public and having been traditionally portrayed as "spouse abuse" or "wife battering". However, others are much subtler and can easily be fit into the "normalcy" of relational cohabitation. Although severely victimized women require unconditional support and such cases demand firm and immediate action, measures should also be contemplated in the sphere of daily routine procedures in the health sector, allowing to deal with the more common and less severe situations, but which nevertheless are not harmless in terms of proper functioning of families and the well-being of their members 3,41,42,43. The application of models to suspect and detect cases; enhancement of reporting systems; development and implementation of follow-up strategies at the local and regional levels; and the improvement and integration of referral networks are some examples of such actions.

A third aspect is that violence must be understood as an interactive event between members of a group, often extending beyond the couple to other family members. Likewise, intimate partner violence should not be viewed as committed exclusive by men against women, but can occur inversely, principally with "everyday" acts. Beyond the macro-structural determinants and explanatory factors, which are certainly important in the genesis and perpetuation of gender conflicts and violence, more attention should be focused on situational issues generating processes which (as discussed above) can be performed by both men and women. It is important to recognize the patterns by which conflictive relations usually evolve, with special emphasis on the "triggers" that tend to spark clashes. The search to understand this dynamic can aid health workers in the early identification and handling of these potentially conflictive relations, prioritizing a family approach as opposed to those based only on exclusive care for the purported victim.

The current findings should be viewed in light of some methodological considerations. In addition to the issues already raised in the section on methods concerning potential problems arising from measurement by proxy or due to the fact that interviews are held in the household, another methodological aspect meriting reflection is an inherent limitation of the measurement instrument itself. Even having received a positive recommendation for use in Brazil 22 and having been chosen for the present survey for reasons of logistic and operational efficiency, the CTS 21 does not allow explicitly informing on the context and consequences of the recorded events, nor does it approach other important forms of intimate partner violence, such as coercion and sexual abuse. In this sense, future surveys might utilize other more complete instruments, such as the Revised Conflict Tactics Scales 44,45,46. Although this would extend the duration of the measurement process, the instrument includes a scale for sexual coercion and allows record- 
ing some injuries suffered by the victim and the resulting need for use of health services. Due to its greater complexity, it offers finer distinction as to the grading of violence and a more enhanced debate as to the distinction between severe forms and more "routine" or "everyday" forms.

As presented in the Introduction, the recognition that intimate partner violence is a problem in Brazil has progressively motivated proposals for broad and multi-sector action. Furthermore, the health sector has been called upon to coordinate and integrate such action. The high prevalence of different types of intimate partner violence in Brazil and their potentially serious repercussions further emphasize this point, effectively placing the problem at the core of major public health concerns in the country. Reinforcing the privileged position of the current study as a watershed for future comparisons, we highlight the need to continuously search for new evidence with a view towards monitoring the magnitude of violence in general and specifically that involving intimate partners. This is an important component to sustain effective intervention measures, one of the pillars in the tripod that also includes ongoing improvement of the pertinent legislation and a progressive enhancement of the integrated networks for action by the legal and health sectors. As indicated by the WHO guidelines 1, now fully supported by the Brazilian Ministry of Health 11,47, it is necessary to prioritize and invest in the evaluation component, a central activity to maintain knowledge up-to-date in relation to a phenomenon which until recently remained concealed and which, as increasingly appears, is neither rare, trivial, or ephemeral.

\section{Resumo}

Este artigo apresenta a prevalência de violência entre parceiros íntimos em 15 capitais brasileiras e no Distrito Federal. Um inquérito de base-populacional em múltiplos estágios foi realizado em 2002/2003, envolvendo 6.760 mulheres (respondentes) de 15 a 69 anos. Usando o instrumento Conflict Tactics Scales - Formulário R, a prevalência global de agressão psicológica, abuso físico "menor" e grave no casal foi de 78,3\%, 21,5\% e 12,9\%, respectivamente. Prevalências variaram distintamente entre as cidades, o abuso físico total indo, por exemplo, de 13,2\% a 34,8\%. Como um todo, as prevalências foram mais altas nas cidades do Norte/Nordeste do que nas do Sudeste/Sul/Centrooeste. Também, todos os tipos de violência entre parceiros íntimos foram mais freqüentes entre casais formados por mulheres jovens ( $<25$ anos) e com menos escolaridade (<8 anos). Desagregando por gênero, ainda que mulheres tendessem a perpetrar pelo menos um item de abuso físico mais amiúde, os escores foram consistentemente mais altos entre parceiros positivos. Os resultados são comparados à literatura externa. Os diferenciais regionais, demográficos e de gênero são discutidos à luz da crescente responsabilidade do setor saúde em relação à violência entre parceiros íntimos.

Violência Doméstica; Estudos Transversais; Prevalência

\section{Contributors}

M. E. Reichenheim participated in the data analysis and as lead author in the elaboration/preparation of the article. C. L. Moraes, M. H. Hasselmann, and E. R. Souza participated in the elaboration/preparation of the article as co-authors. A. Szklo participated in the data processing and analysis and in the elaboration/preparation of the article as co-author. J. A. Lozana participated in the consultancy for elaboration/preparation of the article's methods section. V. Figueiredo participated as the general executive coordinator of the IDCRMRANT Project and in the elaboration/preparation of the article as co-author.

\section{Acknowledgments}

The Household Survey on Risk Behaviors and Reported Morbidity from Non-Communicable Diseases (IDCRMRANT) was financed by the Health Surveillance Secretariat (Secretaria de Vigilância em Saúde - SVS) of the Brazilian Ministry of Health, with counterpart funds from the National Cancer Institute (INCA). The Rio Grande do Norte, Santa Catarina, and Sergipe State Health Departments and the Curitiba Municipal Health Department financed the data collection in their respective capital cities. We wish to thank the Fogarty International Center of the National Institutes of Health (USA) for supporting the research through grant no. R01-HL-73699. M. E. Reichenheim and E. R. Souza are supported by the Brazilian National Research Council (CNPq), grants PQ-300234/ 94-5 and PQ-304939/2003-0, respectively. 


\section{References}

1. Krug EG, Dahlberg LL, Mercy JA, Zwi AB, Lozano R. World report on violence and health. Geneva: World Health Organization; 2002.

2. Heise L, Ellsberg M, Gottmoeller M. A global overview of gender-based violence. Int J Gynaecol Obstet 2002; 78 Suppl 1:S5-14.

3. Campbell J. Health consequences of intimate partner violence. Lancet 2002; 359:1331-6.

4. Jasinski JL, Williams LM. Partner violence: a comprehensive review of 20 years of research. London: Sage Publications; 1998.

5. Gelles RJ. Intimate violence in families. London: Sage Publications; 1997.

6. Ministério da Saúde. Política nacional de redução da morbimortalidade por acidentes e violências. Brasília: Ministério da Saúde; 2001.

7. Ministério da Saúde. Plano nacional de prevenção da violência. Brasília: Secretaria de Atenção à Saúde, Ministério da Saúde; 2004

8. Rodrigues A, Mousse S, Mendes T. Marcadas pelo medo. O Globo 2003, 29 jun; Jornal da Família, p. 5.

9. Soares LE, Soares BM, Carneiro LP. Violência contra a mulher: as DEAMs e os pactos domésticos. In: Soares LE, organizador. Violência e política no Rio de Janeiro. Rio de Janeiro: Instituto de Estudos da Religião/Relume-Dumará; 1996. p. 65-106.

10. Deslandes SF, Gomes R, Furtado MC, Silva P. Caracterização dos casos de violência doméstica contra a mulher atendidos em dois hospitais públicos do Rio de Janeiro. Cad Saúde Pública 2000; 16:129-37.

11. Vargas JD. Familiares ou desconhecidos? A relação entre os protagonistas do estupro no fluxo do Sistema de Justiça Criminal. Rev Bras Ciênc Soc 1999 ; $14: 63-82$.

12. Schraiber LB, d'Oliveira AF. Violence against women and Brazilian health care policies: a proposal for integrated care in primary care services. Int J Gynaecol Obstet 2002; 78 Suppl 1:S21-5.

13. Moraes CL, Reichenheim ME. Domestic violence during pregnancy in Rio de Janeiro, Brazil. Int J Gynaecol Obstet 2002; 79:269-77.

14. Menezes TC, Amorim MMR, Santos LC, Faúndes A. Violência física doméstica e gestação: resultados de um inquérito no puerpério. Rev Bras Ginecol Obstet 2003; 25:309-16.

15. Mendes CHF. Vozes do silêncio: estudo etnográfico sobre violência conjugal e fertilidade feminina [Tese de Doutorado]. Rio de Janeiro: Instituto Fernandes Figueira, Fundação Oswaldo Cruz; 2005.

16. Instituto Brasileiro de Geografia e Estatística. Resolução de conflitos domésticos e violência intrafamiliar nos bairros da Tijuca e Maracanã. Rio de Janeiro: Instituto Brasileiro de Geografia e Estatística; 1999.

17. Soares BM, Gaspary MC, Ingelfritz I. Textos selecionados: violência intrafamiliar contra a mulher. Rio de Janeiro: Subsecretaria de Pesquisa e Cidadania, Secretaria de Estado de Segurança Pública; 1999.

18. NOOS Instituto de Pesquisas Sistêmicas e Desenvolvimento de Redes Sociais. Publicações e atividades. http://www.noos.org.br/atividade.html (accessed on 29/Nov/2005).
19. Coordenação de Prevenção e Vigilância, Instituto Nacional de Câncer. Inquérito domiciliar sobre comportamentos de risco e morbidade referida de agravos não transmissíveis. http://www.inca. gov.br/inquerito/ (accessed on 16/Jun/2005).

20. Kish L. Survey sampling. New Jersey: John Willey \& Sons; 1995.

21. Straus MA. Measuring intra-familiar conflict and violence: the conflict tactics (CT) scales. J Marriage Fam 1979; 41:75-88.

22. Hasselmann MH, Reichenheim ME. Adaptação transcultural da versão em português da Conflict Tactics Scales Form R (CTS-1), usada para aferir violência no casal: equivalências semântica e de mensuração. Cad Saúde Pública 2003; 19:1083-93.

23. Archer J. Assessment of the reliability of the conflict tactics scales: a meta-analytic review. J Interpers Violence 1999; 14:1263-89.

24. Yllö K. Theories and methodology: investigating the problem of family violence. In: Barnett OW, Miller-Perrin CL, Perrin R, editors. Family violence across the lifespan: an introduction. London: Sage Publications; 1997. p. 19-38.

25. Conselho Nacional de Ética na Pesquisa. Normas para pesquisas envolvendo seres humanos (Res. CNS 196/96 e outras). Brasília: Conselho Nacional de Saúde, Ministério da Saúde; 2000.

26. Korn, EL, Graubard BI. Analysis of health surveys. New York: John Wiley \& Sons; 1999

27. Stata Corporation. Survey data manual. Stata statistical software: release 9. College Station: Stata Corporation; 2005.

28. Heise LL, Ellsberg M, Gottemoeller M. Ending violence against women. Baltimore: Population Information Program, School of Public Health, Johns Hopkins University; 1999. (Population Reports, Series L, 11).

29. Heise L, Gracia-Moreno C. Violence by intimate partners. In: Krug EG, Dahlberg LL, Mercy JA, Zwi $\mathrm{AB}$, Lozano R, editors. World report on violence and health. Geneva: World Health Organization; 2002. p. 87-121.

30. Jewkes R, Levin J, Penn-Kekana L. Risk factors for domestic violence: findings from a South African cross-sectional study. Soc Sci Med 2002; 55:1603-17.

31. Taft AJ, Watson LF, Lee C. Violence against young Australian women and association with reproductive events: a cross-sectional analysis of a national population sample. Aust N Z J Public Health 2004; 28:324-9.

32. Harrykissoon SD, Rickert VI, Wiemann CM. Prevalence and patterns of intimate partner violence among adolescent mothers during the postpartum period. Arch Pediatr Adolesc Med 2002; 156:325-30.

33. Rickert VI, Wiemann CM, Harrykissoon SD, Berenson AB. The relationship among demographics, reproductive characteristics, and intimate partner violence. Am J Obstet Gynecol 2002; 187:1002-7.

34. Morse BJ. Beyond the Conflict Tactics Scale: assessing gender differences in partner violence. Violence Vic 1995; 10:251-72.

35. Brush LD. Violent acts and injurious outcomes in married couples: methodological issues in the 
national survey of family and households. Gend Soc 1990; 4:56-67.

36. Straus MA, Gelles RJ. Physical violence in American families: risk factors and adaptations to violence in 8145 families. New Brunswick: Transaction Publisher; 1995

37. Saunders DG. When battered women use violence: husband-abuse or self-defense? Violence Vic 1986; 1:47-60.

38. Marshall LL. Effects of men's subtle and overt psychological abuse on low-income women. Violence Vict 1999; 14:69-88.

39. Johnson MP, Ferraro KJ. Research on domestic violence in the 1990s: making distinctions. J Marriage Fam 2000; 62:948-63.

40. Kantor GK, Jasinski JL. Dynamics and risk factors in partner violence. In: Jasinski JL, Williams LM, editors. Partner violence: a comprehensive review of 20 years of research. Thousand Oaks: Sage Publications; 1998. p. 1-43.

41. Campbell J, Lewandowski LA. Mental and physical health effects of intimate partner violence on woman and children. Psychiatr Clin North Am 1997; 20:353-74.

42. Emery RE, Laumann-Billings L. An overview of the nature, causes, and consequences of abusive family relationships: toward differentiating maltreatment and violence. Am Psychol 1998; 53:12135
43. Reichenheim ME, Hasselmann MH, Moraes CL. Conseqüências da violência familiar na saúde da criança e do adolescente: contribuições para a elaboração de propostas de ação. Ciênc Saúde Coletiva 1999; 4:109-21.

44. Straus MA, Hamby SL, Boney-McCoy S, Sugarman DB. The revised Conflict Tactics Scales (CTS2): development and preliminary psychometric data. J Fam Issues 1996; 17:283-316.

45. Moraes CL, Hasselmann MH, Reichenheim ME. Adaptação transcultural para o português do instrumento "Revised Conflict Tactics Scales (CTS2)" utilizado para identificar a violência entre casais. Cad Saúde Pública 2002; 18:163-75.

46. Moraes CL, Reichenheim ME. Cross-cultural measurement equivalence of the Revised Conflict Tactics Scales (CTS2) Portuguese version used to identify violence within couples. Cad Saúde Pública 2002; 18:783-96.

47. Ministério da Saúde. Direitos humanos e violência intrafamiliar. Informações e orientações para agentes comunitários de saúde. Brasília: Ministério da Saúde; 2001.

Submitted on 01/Aug/2005

Final version resubmitted on 26/Sep/2005

Approved on 28/Sep/2005 